\title{
"I was born with a few disabilities - this does not stop me from trying my best and I give most things a go."
}

\section{Inclusion from the perspectives of students with disabilities}

\author{
Jude MacArthur and Berni Kelly
}

T he quotation in the title of this article comes from Ryan, a New Zealand secondary-school student, in a statement to his teachers. Ryan wanted his teachers to recognise his impairment-related needs and experiences at school and to take these into consideration in their teaching. His statement also referred to the various barriers he faced at school that meant he needed help or additional time for school activities. Ryan was particularly keen to point out to teachers that he was still able to participate at school and that teachers could talk to him about his needs and experiences if they wished.

While this statement represents Ryan's maturity and ability, it also highlights a reversal of roles, in which he has taken responsibility for educating his teachers. An exploration of what inclusion looks like in schools and classrooms should include the voices of children and young people with disabilities, like Ryan, although this has only recently become a priority in education research. Research that highlights students' perspectives and the realities of their day-to-day schooling can reveal a different picture from that which highlights the perspectives of adults. New Zealand and international research that has taken this approach shows that what students say about school can be a critical starting point for teachers in reflecting on their practice and considering how best to support the participation and learning of students with disabilities at school (Davis \& Watson, 2001; Fraser, 2001; Hunton \& Doyle, 1999; Lyle, 2002; MacArthur \& Gaffney, 2001).

Special, regular, and inclusive

\section{education}

The terms "regular education" and "special education" are used in this paper. "Regular education" refers to education in a classroom where students with disabilities are taught alongside their non-disabled peers. "Special education" refers to schooling in separate locations, such as special schools, units, or classes, including the structures used in any school that identify students as "special" (such as withdrawal from the classroom for specialist teaching or therapy or high levels of one-to-one adult support). This interpretation reflects the current literature, which associates "special education" with particular ways of thinking about students with disabilities and with educational structures that differentiate students from their peer groups (McDonnell, 2002).

The terms "inclusive education" and "inclusion" are defined in a wide range of ways in the research literature, and it is common for these terms to be misused. In particular, inclusion is often associated with the simple physical location of students with disabilities in regular schools and classrooms, without any recognition of the need for change in the mainstream to accommodate student diversity. However, many researchers exploring this area describe inclusive education as a complex and evolving concept based on key ideas about social justice. Inclusion is concerned with meeting the diverse needs of allstudents (including students with disabilities) in an equitable and accepting education system (Slee, 2000, 2001). It is described as a process that schools engage in to increase the learning and participation of all students and to reduce the exclusionary pressures that limit participation for some children and young people (Booth $\&$ Ainscow, 2002). Inclusive education is therefore strongly associated with change in:

- educational policy (Dyson, Howes, \& Roberts, 2002; Slee, 2001);

- schools (in particular, school culture, principal leadership, and teacher values); and

- teaching practice (Alton-Lee, 2003; Dyson, Howes, \& Roberts, 2002).

British researcher Mel Ainscow (1999, p. 218) defines inclusion as:

A process of increasing the participation of pupils in, and reducing their exclusion from, the cultures, curricula, and communities of their local schools, not forgetting, of course, that education involves many processes that occur outside of school.

\section{Aim of this discussion}

This article discusses some of the research into the school experiences of students with disabilities. It includes explorations of:

- students' perspectives on the curriculum;

- teaching approaches used in the classrooms;

- being made to feel "different";

- students' social lives at school; and

- students' participation in educational decisions that directly affect them.

In an effort to try to redress the imbalance that has prioritised adult perspectives on inclusion, this paper explores children's and young people's experiences as they describe them. In presenting these perspectives, we are mindful that students with disabilities often describe negative experiences of school. As researchers working 
in this field we are aware of the challenges of teaching diverse groups of students and of the need for teachers to be well supported pedagogically and in terms of resources and working conditions. However, students with disabilities raise some issues that can be addressed quite readily by teachers taking a reflective and responsive approach to their everyday practice. Understanding how students with disabilities experience school is a crucial part of the body of knowledge needed for teachers and schools to move towards inclusion.

In order to preserve the anonymity of the research participants in our current study, pseudonyms are used in this paper and identifying features have been removed.

\section{"Why don't we have to read what the other students are reading?"}

\section{Learning through a diverse and meaningful curriculum}

Research shows that students with disabilities have aspirations for their school life, their learning, and their future. In a British study, secondary school students with a range of disabilities who were studying in a regular school described the purpose of going to school as having a "good education” (Ainscow, Booth, \& Dyson, 1999). However, the research looking at what students with disabilities learn at school shows that teachers do not always hold the same expectations as their students. Stereotyping of students with disabilities in schools and low teacher expectations are described in the research as contributing to an unchallenging curriculum that can limit students' opportunities for learning. It is not surprising, then, to find that young people with disabilities are more likely than their nondisabled peers to leave school without qualifications, to be unemployed, and consequently to experience a poor quality of life as adults (Fergusson, Swain-Campbell, \& Horwood, 2002; Kraemer, McIntyre, \& Blacher, 2003; Statistics New Zealand, 2002).

Students have identified several instructional practices in schools that they perceive as limiting their opportunities for learning important skills. A North American intermediate-aged student described being withdrawn from his regular class to a resource room to develop his literacy skills, and asked:

Why don't we have to read what the other students are reading? My teacher doesn't help to read the words; she doesn't tell me how to break the word up into pieces so that I can pronounce it. She tells me all of the words that I don't know, or she'll just

read the whole thing herself.

McCray, Vaughn, \& Neal, 2001, p.27

Students in this study wanted their teachers to

- promote independent learning;

- use consistent and effective reading instruction;

- take into account their reluctance to be identified as different from their peers; and

- use interesting and varied reading materials. North American researchers Kliewer and Biklen (2001) are critical of some teachers who make assumptions about the inability of students with disabilities. In contrast, they describe other teachers who supported the development of literacy skills in students with disabilities by focusing on their relationships and engagement with peers and teachers. One secondary-school student in this study, Michael, used his communicator to type out what he thought made a good teacher in this regard:

Respect comes with love and understanding each kid's abilities and the desire to teach so therefore teachers must have a desire to teach everyone. They must realise that their dreams are not ours. Ask us what we will need to be independent person later in our life. Teach good skills in a respectful way. Conversations with me will tell $\mathrm{u}$ if I'm happy.

Kliewer \& Biklen, 2001, p. 11

Students describe low teacher expectations as restricting access to a diverse and relevant curriculum (Cooke, Swain, \& French, 2001; Hunton \& Doyle, 1999). Peter, a 22-year-old North American college student, for example, criticised "boring teachers" who delivered meaningless functional curricula:

I had a lot of boring teachers in high school because I was in special ed. In high school, if you're in special education classes, they make you do stupid things like brushing your teeth in school. That isn't good because that stuff you do in kindergarten. I don't think the other kids in special education liked it either... There was always a teacher or aide hanging on my back like I was a baby.

Hunton \& Doyle, 1999, p. 22

Peter also explained that he disliked not having friends, being teased by other students at school because of his disability, and being excluded from sports or clubs at high school. He explained that since leaving school he had started to develop friendships and was treated more fairly rather than having others speak to him in a condescending manner. Reflecting on his college experiences, he concluded:

I learn a lot more stuff now, too. I get to learn stuff I never learned before. The important things that I learned this year are how to speak more clearly and to share my ideas. I've also learned how to joke around with people. I really like college. Now people call me by my name... they don't call me names. My name is Peter and I am not a special ed. kid anymore

Hunton \& Doyle, 1999, p. 22

In Ballard and McDonald's (1999) New Zealand study, Marilyn, a woman in her thirties who had a significant physical disability, described the impact of both the low and the high expectations of her secondary school teachers as critical to her academic achievement. She felt that supportive teachers did not see her primarily as someone with a disability, while an unsupportive science teacher limited her opportunities for learning. Marilyn explained that in science class she was expected to "just watch and learn" rather than actively participating (p. 100). Marilyn felt there was an expectation that people with disabilities would not be competent in science and described this attitude as, "really sad... especially when... you would make a great scientist" (p. 100).

Students have emphasised the need for their education to provide them with the skills necessary for a good quality of life as adults and for further education or employment (Davis \& Watson, 2001; Kraemer, McIntyre, \& Blacher, 2003; Lovitt, Plavins, \& Cushing, 1999). At secondary school, the curriculum needs to be geared towards students' transition to adult life and be responsive to their aspirations and preferences (Cooney, 2002). However, the research suggests that schools that fail to prepare students with disabilities for transition to adult life, provide them with limited career advice, and make few opportunities for them to learn work-related skills. Researchers with disabilities working on the "Educable Project" (2000) study in Northern Ireland interviewed young adults with disabilities who had attended both special and regular schools. These young adults felt strongly that, in retrospect, school had not prepared them well for adult life. They felt they were not encouraged to undertake serious study. They had also encountered negative teacher attitudes and low expectations that demonstrated disrespect towards students with disabilities and undermined their ability to achieve their own post-school aspirations. The researchers concluded (p. 56):

No one expects us to do well in exams and go on to have a career or even a decent job. Changing this means challenging a mindset that sees the disability not the person and that fails to recognise that 
while it might take a young person with a disability longer to achieve goals we can still do it.

\section{Teaching, teacher aides, and feeling different}

Hulston's (2000) New Zealand research emphasises that teachers need to take responsibility for all of their students. Her study found that students with disabilities were commonly allocated to teacher aides who were unsupported by teachers and unprepared in terms of their training and knowledge of the curriculum to support student learning. Some authors have been critical of the extent to which many students with disabilities are taught by teacher aides and have little contact with their class teachers (Ainscow, 2000; Giangreco, Edelman, \& Broer, 2003; Rutherford, 2002). In the British "Lewisham Project", Ainscow (2000) found that the continual availability of additional adult support meant in some cases that students ceased to even participate in lessons. When teacher aides grouped disabled children together in regular classrooms (a common strategy in New Zealand classrooms), children interacted with the aides rather than with the teachers or their peers. In Shaw's (1998) study of children's perspectives on teacher-aide support, children were worried that teacher aides were too obtrusive or hindered their ability to make friends and that they would be unable to participate if their aide were not available. One child involved in this study wrote the following job description for a teacher aide (p.78):

Person must not want job for power. Person must be able to listen to child. Person must understand limits of safety. Person must be able to help with friendships. Person must be strong and able to lift. Person must not get ill regularly. Person must listen to my mummy.

Likewise, students with disabilities in Davis and Watson's (2001) British study "Life as a Disabled Child", highlighted the high degree of surveillance and control by adults in the classroom. Students emphasised their need for privacy and worried that close adult support made it difficult for them to develop friendships and positive relationships with their classmates.

In our own research, 11- to 14-year-old students with disabilities describe a heightened sense of feeling different and express a strong desire to be like their peers. We have observed students resisting teaching approaches that separate them from the activities of the classroom and identify them as different (such as close teacher-aide support or withdrawal from the classroom for specialist teaching or therapy).
Thirteen-year-old Pete described what it felt like to be withdrawn from the classroom for specialist support:

Interviewer: Do you always get taught in the class with everyone else?

Pete: Yeah or other people come to see me in the class or take me out... You know science lab rats? I'm like that. People come to test me, and ask me (questions) to learn about how autism works for other people.

Similarly, Luke has expressed as a learning goal a desire to "speak like the other children at school". Emma tries to do what others in her class do and does not like using her computer because it makes her feel different from the others in her class. Kate says her teacher does different things with her in class in comparison with other students because "I can't do things that are hard." She also describes feeling unhappy about this differentiation and wants to be taught the same things as the other students. In our research we have observed some teachers undertaking lessons that emphasise participation for all, while also meeting the diverse learning needs of students. In contrast, other teachers find it difficult to achieve this level of engagement in their classrooms. This raises questions about the preparedness of teachers to work with diverse groups of students and about their needs for pedagogical support.

Schools have the capacity to either support or diminish students' sense of belonging in their class and peer group. Some teachers in our research, for example, are particularly sensitive to their students' wishes to remain in class, to participate with their peers, and not to be differentiated. Some teachers have actively challenged teaching approaches in their own schools that exclude students and have initiated positive and creative changes to support the inclusion of students with disabilities. One school recognised that withdrawal from the classroom made children with disabilities feel different and made withdrawal of groups of students a class-wide routine for all students, using these for a variety of purposes. Another school has used the leisure interests of a student with disabilities to set up a school-wide club that enhances students' social engagement. Many of these positive changes have happened as the result of strong relationships between teachers and students that foreground individual children's experiences and preferences.

\section{"I thought the helpers were} taking away my friend." Students' perspectives on their school social lives
The New Zealand curriculum prioritises children's social relationships as a key area for focus in schools, but New Zealand and overseas research indicates that children with disabilities are very likely to experience difficulties in this area (Davis \& Watson, 2001; Lovitt, Plavins, \& Cushing, 1999; MacArthur \& Gaffney, 2001; MacArthur, 2002; Meyer, 2001).

Research shows that bullying is a salient issue for students with disabilities (Davis \& Watson, 2001; MacArthur \& Gaffney, 2001). In this work and in our current research with 11- to 14-year-olds, students describe their experiences of bullying at school. They are often fearful, and many are critical of what they perceive to be minimal responses by their teachers and school principals.

Difficulties with friendships are also common and are heightened when children attend schools out of their home districts (Davis \& Watson, 2001; MacArthur \& Gaffney, 2001; Meyer, 2001). Children involved in Davis and Watson's (2001) British study wanted be part of their peer group at school but described barriers to their full participation. In addition to adult surveillance, children encountered physical barriers (such as poor access to playgrounds and buildings) and attitudinal barriers from peers (including social exclusion and physical, emotional, and verbal bullying). Peer relationships were often dominated by an assumption of need and care, with non-disabled students being cast as helpers rather than as equals. Non-disabled peers were generally unwilling to associate with disabled children or would do so only in certain contexts, which limited students' choices in their relationships.

Similar barriers to friendship are described in recent research in New Zealand (MacArthur, 2002; MacArthur \& Gaffney, 2001). MacArthur and Gaffney (2001) interviewed New Zealand students with disabilities who described being lonely, particularly during unstructured break times. This work (and our current research) suggests that despite an emphasis in the curriculum on children's social experiences, the area of friendships for children with disabilities is rarely prioritised in schools, and is sometimes ignored altogether. On the other hand, teachers who see this area as important often struggle to know how to support this aspect of their students' lives.

Some teachers in Lyle's (2002) New Zealand study were observed to implement "support" strategies that actually interfered with children's attempts to establish relationships on their own terms. For example, although non-disabled friends described helping a classmate with a disability throughout the day as being an ordinary 
part of their role as friends, teachers established a buddy system for non-disabled students to "mind" students with disabilities before school. One friend complained about this, arguing that this was her natural role as a best friend (p. 31):

I was sad. I thought the helpers were tak-

ing away my friend.

Children had also requested that the student with a disability be allowed to eat her lunch with them, but the teacher aide had chosen a separate place where there was less distraction by the noises and social advances of her peers. This study and others reiterate the point that friendship development is associated with facilitative behaviours by teachers and parents and that segregation from peers and low expectations about the possibility of friendship are key factors working against the establishment of friendships (Evans \& Meyer, 2001; Meyer, 2001). These studies suggest that adults need to be particularly sensitive to children's social experiences and to children's interpretations of these, giving them priority in their planning and teaching.

\section{Student participation in education processes}

British researchers, Kenworthy and Whittaker (2000), note that students are rarely consulted about educational decisions, such as which type of school they would like to attend or what they deem their needs to be. Likewise, in New Zealand, Kavermann (1998) notes that the perceptions of students with disabilities about their school lives have rarely been investigated. These authors argue that students with disabilities should be consulted about their school experiences to ensure a holistic evaluation of educational supports. This would be in accordance with the United Nations' Convention on the Rights of the Child, which highlights the right of students with disabilities to be consulted and have a say in decisions affecting their lives (Bray \& Gates, 2000).

Listening to students with disabilities and promoting their participation at school are key issues that have been raised by a range of researchers. Rogers (2002) examined the decision-making processes for an intermediateaged student in special education who wanted to move to a regular school. The author described two special-education meetings that appeared to offer choices but in fact coerced the child and her parent to support the professional decision that the child should remain in special education. Cooke, Swain, and French (2001) also highlight the unequal relationship between students with disabilities and the non-disabled adults who make educational decisions affecting their lives. They express concern that students are excluded from planning meetings where educational decisions are made and are not consulted about what they personally value about their education or what they need to feel included in regular education settings. Cooke, Swain, and French (2001) emphasise that students with disabilities can communicate what inclusion means for them and that their views should be taken seriously.

Similarly, other researchers have argued that regular schools will not become truly inclusive until adults controlling schools take account of students' views of educational processes, and policy makers adopt a more complex understanding of the context of inclusion (Davis \& Watson, 2001; Ware, 2002). Children's perspectives can provide insights into life in the playground and classroom which adults may otherwise find elusive, and highlight areas of their school life where teachers can provide support. Corbett (1999) emphasises that enhancing teacher practice involves listening with respect to the previously "unfamiliar voices" of students with disabilities and their parents as they share their perspectives and experiences, and giving validity to those voices when decisions are made about curriculum, teaching, and relationships at school.

\section{Conclusion}

Whilst it is acknowledged that some of the issues raised by research are related to macroinadequacies at policy and resource levels, the research literature exploring the perspectives and experiences of students with disabilities also indicates key areas that may be more immediately addressed by teachers in New Zealand schools and classrooms.

In a range of New Zealand and international research, students with disabilities have emphasised that they want teachers to view them as children and young people first. Students with disabilities have clearly stated that they prefer teachers who focus on their strengths and learning potential rather than their perceived deficits and the effects of impairment (Davis \& Watson, 2001). In this way, children with disabilities are viewed as part of the group of all children in school, rather than being identified as different. Within this context, teachers recognise the effects of teaching approaches, school organisation, and peer group attitudes on the educational experiences of students with disabilities and do not simply attribute educational failure to the limitations of individual students.

An important aspect of inclusive educational experiences is the development of engaging, sup- portive, and trust-based relationships between students with disabilities and their peers and teachers (Alton-Lee, 2003). It is evident from the research reported that students with disabilities experience bullying and discrimination at school and experience a sense of differentiation from their peers. These experiences contrast with the students' desire to be a part of the group of all children. Within this context, teachers have important roles to play in prioritising and supporting the development of friendships and caring school environments.

Research suggests that students with disabilities require access to a challenging and relevant curriculum that is meaningful to their own personal, social, academic, and career goals. Within New Zealand, there is a need for further work to ensure that the curriculum itself is inclusive. However, at individual school levels, low teacher expectations for students with disabilities is an issue of concern and is highlighted as a major barrier to learning for students with disabilities. Students prefer teaching approaches that are motivating, engaging, and creative and that promote independence rather than dependence.

Research indicates that teacher reflexivity is central to the development of teacher practice. Effective teachers think critically about their daily practice, question their own assumptions about the capacity of students with disabilities to learn, and reflect on the school barriers that may restrict student learning. In this way, teachers actively evaluate and seek to enhance their approach to teaching students with disabilities in their own classrooms. This does require teachers to be willing to make necessary changes and to accept responsibility for all students in their classrooms, including students with disabilities.

\section{References}

(also recommended readings*)

Ainscow, M. (1999). Understanding the development of inclusive schools. London: Falmer Press.

Ainscow, M. (2000). The next step for special education: Supporting the development of inclusive practices. British Journal of Special Education, 27(2), 76-80.

Ainscow, M., Booth, T. \& Dyson, A. (1999). Inclusion and exclusion in schools: Listening to some hidden voices. In K. Ballard (Ed.), Inclusive education: International voices on disability and justice, (pp. 139-151). London: Falmer Press.*

Alton-Lee, A. (2003). Quality Teaching for Diverse Students in Schooling: Best Evidence Synthesis. Wellington; Ministry of Education.

Ballard, K., \& McDonald, T. (1999). Disability, inclusion and exclusion; some insider accounts and interpretations. In K. Ballard, (Ed), Inclusive education; International voices on disability 
and justice, (pp. 197-115). London: Falmer Press.*

Booth, T., \& Ainscow, M. (2002). Index for inclusion: developing learning and participation in schools. Bristol, U.K.: Centre for Studies in Inclusive Education.

Bray, A., \& Gates, S. (2000). Children with disabilities: Equal rights or different rights? In Smith, A., Gollop, M., Marshall, K. \& Nairn, K. (Eds.), Advocating for Children: International Perspectives on Children's Rights, (pp. 32-41) Dunedin: University of Otago Press.

Cooke, T., Swain, J., \& French, S. (2001). Voices from segregated schooling: Towards an inclusive education system. Disability and Society, 16(20), 293-310.*

Cooney, B. F. (2002). Exploring perspectives on transition of youth with disabilities: Voices of young adults, parents and professionals. Mental Retardation, 40(6), 425-435.

Corbett, J. (1999). Inclusive education and school culture. International Journal of Inclusive Education, 3(1), 53-61.

Davis, J., \& Watson, N. (2001). Where are the children's experiences? Analysing social and cultural exclusion in "special" and "mainstream" schools. Disability and Society, 16(5), 671-687.*

Dyson, A., Howes, A., \& Roberts, B. (2002). A systematic review of the effectiveness of schoollevel actions for promoting participation by all students. London: The EPPI Centre. Retrieved 12 August 2004 from http://eppi.ioe.ac.uk/ EPPIW eb/home.aspx?page $=/$ reel/ $/$ review_ groups/inclusion/review_one.htm

Educable Project (2000). No choice: No chance. The educational experiences of young people with disabilities. Belfast, Northern Ireland: Save the Children and Disability Action.

Evans, I., \& Meyer, L. (2001). Having friends and Rhett Syndrome: How social relationships create meaningful contexts for limited skills. Disability and Rehabilitation, 23(3/4), 167-176.

Fergusson, D. M., Swain-Campbell, N., \& Horwood, L. J. (2002). Outcomes of leaving school without formal educational qualifica- tions. New Zealand Journal of Educational Studies, 37(1), 39-55.

Fraser, D. (2001). The educational needs of children with cancer. Hamilton: The Waikato Institute for Research in Learning and Curriculum.

Giangreco, M., Edelman, S., \& Broer, S. (2003). Schoolwide planning to improve paraeducator supports. Exceptional Children, 70(1), 63-79.

Hulston, S. (2000). "Blurring the edges." An indepth qualitative study of inclusion and the curriculum in a New Zealand secondary school. Unpublished Thesis, Canterbury: University of Canterbury.

Hunton, P., \& Doyle, M. B. (1999). I'm not in special education anymore: My name is Peter. TASH Newsletter, 10 (October), 22.

Kaverman, A. (1998). The inclusion of students with special educational needs in regular secondary school classes; perspectives of educators, students and parents. Report submitted in partial fulfilment of the requirements for the degree of Master of Education (Special Education). Hamilton: Massey University.

Kenworthy, J., \& Whittaker, J. (2000). Anything to declare? The struggle for inclusive education and children's rights. Disability and Society, 15(2), 219-231.

Kliewer, C., \& Biklen, D. (2001). "School's not really a place for reading:" A research synthesis of the literate lives of students with severe disabilities. JASH, 26(1), 1-12.

Kraemer, B. R., McIntyre, L. L., \& Blacher, J. (2003). Quality of life for young adults with mental retardation during transition. Mental Retardation, 41(4), 250-262.

Lovitt, T., Plavins, M., \& Cushing, S. (1999). What do pupils with disabilities have to say about their experience in high school? Remedial and Special Education, 20(2), 67-76.

Lyle, J. (2002). A friend indeed: Understanding the perspectives of non-disabled primary school children who have a friend with a significant disability. Research study completed in partial fulfilment for the degree of Postgraduate Diploma in Child Advocacy. Dunedin: Uni- versity of Otago.

MacArthur, J. (2002). Students with disabilities and their parents talk about friendships and relationships at school. set: Research Information for Teachers, 1, 13-18.*

MacArthur, J., \& Gaffney, M. (2001). Bullied and teased, or just another kid? The social experiences of students with disabilities at school. Wellington: New Zealand Council for Educational Research*

McCray, A. D., Vaughn, S., \& Neal. L. V. I. (2001). Not all students learn to read by third grade: Middle school students speak out about their reading disabilities. The Journal of Special Education, 35(1), 17-30.

McDonnell, P. (2003). Developments in special education in Ireland: Deep structures and policy making. International Journal of Inclusive Education, 7(3), 259-269.

Meyer, L. (2001). The impact of inclusion on children's lives: Multiple outcomes, and friendships in particular. International Journal of Disability, Development and Education, 48(1), 9-31.*

Rogers, R. (2002). Through the eyes of the institution: A critical discourse analysis of decisions making in two special education meetings. Anthropology and Education Quarterly, 33(2), 213-237.

Rutherford, J. (2002). Getting a fair go? Issues and practices regarding teacher aide support of students with disabilities. Report on a Winston Churchill Fellowship report. Dunedin: Dunedin College of Education.

Statistics New Zealand. (2002). Disability Counts. Wellington: Statistics New Zealand.

Shaw, L. (1998). Children's experiences of school. In C. Robinson \& K. Stalker, (Eds), Growing up with a disability (pp. 73-84). London: Jessica Kingsley Publishers.

Slee, R. (2000). Talking back to power. The politics of educational exclusion. Keynote address at the International Special Education Congress 2000, "Including the Excluded", University of Manchester, 24-28 July.

Slee, R. (2001). Inclusion in practice: does practice make perfect? Educational Review, 53(2), 113-123.

Ware, L. (2002). A moral conversation on disability: Risking the personal in educational contexts. Hypatia, 17(3), 143-172.

\section{Acknowledgements}

The authors wish to acknowledge the financial support of the New Zealand Royal Society's Marsden Fund and the New Zealand Ministry of Education for help in researching some of the literature and ideas presented in this paper. The views expressed in this paper do not necessarily reflect those of the Ministry of Education.
Dr Berni Kelly is a qualified social worker and has previously worked as a researcher at the University of Ulster and the National Children's Bureau based in Northern Ireland. Ber$\mathrm{ni}$ is currently a researcher at the Donald Beasley Institute in Dunedin conducting research on the impact of school experiences on disabled children's developing identity and the delivery of needs assessment and service co-ordination for disabled children and young people. 